\title{
Anthós
}

\section{Between Two Jailers: Women's Experience During Colonialism, War, and Independence in Algeria}

Adrienne Leonhardt

Portland State University

Follow this and additional works at: https://pdxscholar.library.pdx.edu/anthos

Part of the African History Commons, and the Islamic World and Near East History Commons Let us know how access to this document benefits you.

\section{Recommended Citation}

Leonhardt, Adrienne (2013) "Between Two Jailers: Women's Experience During Colonialism, War, and Independence in Algeria," Anthós: Vol. 5: Iss. 1, Article 5.

https://doi.org/10.15760/anthos.2013.43

This open access Article is distributed under the terms of the Creative Commons Attribution-NonCommercialShareAlike 4.0 International License (CC BY-NC-SA 4.0). All documents in PDXScholar should meet accessibility standards. If we can make this document more accessible to you, contact our team. 


\section{Between Two Jailers ${ }^{1}$ : Women's Experien ce During Colonialism, War, and In dependence in Algeria}

Adrienne Leonhardt

After a nearly 130-year regime of violence and oppression under French colonialism, Algerians began their struggle for independence in 1954. Nearly one million people were killed, centuries-old traditions were broken, and the country was torn apart. ${ }^{2}$ The Algerian war has also been described as a "moment in which gendered, religious, and ethnic identities were challenged."3 Within Algerian society and the French colonial regime at the time, expectations were deeply ingrained regarding the status and rights of women. Particularly significant is the impact that the war had on shaping Algerian women's role in society. Both sides used women during the

${ }^{1}$ From the quote by Fadila Ahmed: "We, the women of Algeria, have two jailers: colonialism [...] and the apathetic creatures who cling on to customs and traditions inherited not from Islam but from their ignorant fathers. The second jailer is worse than the first." Neil MacMaster, "The Colonial 'Emancipation' of Algerian Women: the Marriage Law of 1959 and the Failure of Legislation on Women's Rights in the Post-Independence Era," Vienna Journal of African Studies 12 (2007): 97.

2 Miriam Cooke, Deconstructing War Discourse: Women's Participation in the Algerian Revolution (East Lansing: Michigan State University, 1989), 2.

${ }^{3}$ Natalya Vince, "Transgressing Boundaries: Gender, Race, Religion, and 'Francaises Musulmanes' during the Algerian War of Independence," French Historical Studies 33, no. 3 (2010): 448. 
Anthós, Vol. V, Issue 1

conflict to symbolize a greater cause, appropriating their image to form a particular narrative of events. ${ }^{4}$

The idealized constructs of gender propagated by both Algerian men and the French colonial regime were used to project a certain image of women's social and political roles that served their own interests during the war, with few tangible benefits for women themselves. Although many women suffered and risked their lives in the war against French occupation, their contributions to an Algerian victory did not help them achieve equal rights once independence was declared in 1962. My research provides a chronological historical analysis of the role of women in the Algerian war. I use primary and secondary historical and literary sources to argue that despite participation in the liberation struggle Algerian women remained marginalized in the new independent Algerian society.

Although Algeria was colonized in 1830 for mostly economic and political reasons, it was justified under the guise of "la mission civilisatrice" (civilizing mission) in part because the French saw Algerian culture as backwards and underdeveloped, especially in regards to their treatment of and behavior towards women. ${ }^{5}$ Unlike some Middle Eastern countries in the late $19^{\text {th }}$ century with burgeoning feminist movements, Algeria was more restrictive towards women's rights. Algerian culture in the late $19^{\text {th }}$ century was conservative and patriarchal, based on a form of Islamic law that favored the male family line. ${ }^{6}$ After colonization, French settlers ("pieds-noirs") slowly began to take control of Algeria's land, government, economy, and culture, altering it to French standards. To the French, Algerian women were seen as the "oppressed of the

${ }^{4}$ Ibid., 1.

${ }^{5}$ Ibid., 142.

${ }^{6}$ Nikki R. Keddie, Women in the Middle East: Past and Present (Princeton, New Jersey: Princeton University Press, 2006), 140. 
oppressed."7 Despite this attitude, however, French policies towards Algerian women's rights were ambiguous and never significantly improved under colonization. By 1954, when war broke out, women were completely excluded from public life. Only $4.5 \%$ were literate, few had jobs or went to school, and they had no voting rights. ${ }^{8}$

By the late 1950s the independence movement began gaining momentum and violence continued to escalate. The French government and army became concerned with reports of female involvement in the leading independence group, the National Liberation Front (FLN), and decided to offer a "counter-strategy to win hearts and minds." Previously, under the "statut personnel" (personal status law) of the colonial regime, the French had asserted their dominance by denying Algerians equal rights as French citizens: however, "as a quid-proquo, the colonial government promised to protect Islamic law in the crucial area of marriage and family legislation, a 'reserved' area that would be guarded from the incursion of western values and secular French models of society." ${ }^{\prime 0}$ Despite this agreement, in the midst of armed conflict in 1959, the French regime attempted an alternate approach at gaining support from Algerians by enacting a series of "reformist, liberal emancipation measures" that would target women's rights within marriage, family law, and education. Their main plan for retaining "l'Algérie française" (French Algeria) was stopping the rebellion through economic modernization and social reforms that promoted women's education, voting rights, unveiling campaigns, health care, and jobs. ${ }^{11}$

7 Cooke, Deconstructing War Discourse, 2.

${ }^{8}$ Daniele Djamila Amrane-Minne and Farida Abu-Haidar, "Women and Politics in Algeria from the War of Independence to Our Day," Research in African Literature 30, no. 3 (1999): 62.

${ }^{9}$ MacMaster, “The Colonial ‘Emancipation’ of Algerian Women,” 91-92.

10 Ibib., 97.

11 Ibid., 96. 
Anthós, Vol. V, Issue 1

The French believed that appealing to women by improving their status would break up the independence movement, since women were seen as symbols of Algerian national identity and culture. ${ }^{12}$ These policies were intended to liberate Muslim women from the "ignorance and the crushing weight of patriarchal domination."13 But the unspoken reality was in fact an "assimilationist agenda" that sought to convert Algerian women to Western culture, believing that the appeal of Western-style reforms could win their support. ${ }^{14}$ In reality, the so-called emancipation reforms actually put the majority of Algerian women at a disadvantage. The changes to marriage law were ignored, especially in rural areas, and the reforms generated intense backlash towards women's rights. Many Algerian men felt threatened by the "moral interference" of the French reforms and promotion of women's rights, fearing that women would become powerful and threaten social order and tradition. ${ }^{15}$ They considered the reforms an attack on Islam and Algerian culture, which they resisted by emphasizing the necessity of religious values, family, and the modest dress and seclusion of women. ${ }^{16}$

Similarly, the FLN was forced into a position where they could not agree with the advancement of women's rights without being seen as accepting the reforms of the colonial state, their enemy, as a positive change. ${ }^{17}$ As the revolution gained momentum, so did the rise of conservatism among Algerians as a defense against what they saw as the violation of their culture by a colonial power. In particular, the traditional image of women in Algerian society came to symbolize the

12 Ibid.

13 Ibid.

14 Ibid.

15 Cooke, Deconstructing War Discourse, 7.

16 Suad Joseph and Susan Slyomovics, eds., Women and Power in the Middle East, (Philadelphia: University of Pennsylvania Press, 2000), 28.

17 Cooke, Deconstructing War Discourse, 7. 
national identity the FLN was fighting for. ${ }^{18}$ Women's participation in the liberation struggle, however, seemed poised to challenge this notion of the traditional Algerian woman. Writing about the revolution, anti-colonialist author and psychologist Frantz Fanon predicted the "birth of a new society" and a "radical mutation" of the status of women, gender relations, and traditional family structures. ${ }^{19}$ The reality of Fanon's predictions would, however, take another form. ${ }^{20}$

Women's liberation was low on the FLN's list of priorities -they were primarily concerned with achieving independence from the French colonial regime and protecting Algerian society from what they saw as encroaching secular Westernism. ${ }^{21}$ The public perception of Algerian women, however, became central to the FLN's resistance narrative. In particular, the most visible symbol of the traditional culture the FLN was trying to protect was the veil, which came to symbolize "the dignity and validity of all native customs coming under attack (relating to women) and the need to affirm them as a means of resistance to Western domination." 22 Wearing the veil was both an act of resistance to the colonial powers and a useful tool for carrying out attacks: Fanon praised its "revolutionary value" 23 as it allowed the female fighters to smuggle weapons and bombs and travel unnoticed by French soldiers and police.

Despite these powerful connotations Fanon also wrote that most Algerians embraced the wearing of the veil, as "tradition demanded the rigid separation of the sexes." ${ }^{24}$ While the FLN recruited a small

18 Keddie, Women in the Middle East, 142.

19 MacMaster, “The Colonial ‘Emancipation’ of Algerian Women,” 92.

20 Ibid.

21 Joseph and Slyomovics, Women and Power in the Middle East, 28.

22 Leila Ahmed, Women and Gender in Islam: Historical Roots of a Modern Debate (New Haven, CT: Yale University Press, 1993), 164.

${ }^{23}$ Ibid.

24 Ibid. 
number of women as fighters, they encouraged women to support their struggle through what they called "patriotic motherhood": being good wives and mothers who would teach their sons to value religion and "preserve traditional moral standards" as a way of molding the next generation of Algerians. ${ }^{25}$ Women's participation in other aspects of the war was valued to some extent, but they were never given a legitimate voice or position in the liberation movement. ${ }^{26}$ Expectations of women were not altered because of their participation in the war.

The FLN, however, had no problem using female fighters as propaganda for their cause. In response to the French emancipation reforms, the FLN launched its own publicity campaign, claiming "women could only achieve equality by fighting for a country freed from colonial domination." 27 These women received attention in the global media as heroines of the revolution who were challenging stereotypes of Muslim women as passive victims of Islamic male oppression. ${ }^{28}$ The FLN's wartime newspaper El Moudjahid published weekly excerpts from a diary of a young female fighter. ${ }^{29}$ They also publicized stories depicting the sacrifices of Algerian female fighters in order to incite international protest against the French regime, especially among left-wing intellectuals in Europe and the United States, portraying them as innocent victims against the French aggressors. ${ }^{30}$ Using women in this way changed the image of the war from radical Arabs terrorizing peaceful Europeans to that of the

25 Marie-Aimee Helie-Lucas, "Women, Nationalism, and Religion in the Algerian Liberation Struggle," in Opening the Gates: An Anthology of Arab Feminist Writing, ed. Margot Badran and Miriam Cooke, 2nd ed. (Bloomington: Indiana University Press, 2004), 108.

26 Joseph and Slyomovics, Women and Power in the Middle East, 28.

27 MacMaster, “The Colonial 'Emancipation’ of Algerian Women,” 92-93.

28 Ibid.

29 Vince, "Transgressing Boundaries," 446.

30 Ibid. 
colonized fighting back against a brutal oppressor: "The discourse on Algerian women was an important weapon in combating the French government's depiction of a nationalist struggle as a minority movement led by religious fanatics with a pan-Arab agenda." 31 The narrative of the Algerian female fighter supported a romanticized version of the anti-colonialism struggle, helping to bring the FLN sympathy and support. ${ }^{32}$

There remained, however, an underlying sense of superficiality in the FLN's depictions of the struggles of Algerian women. Women's actual experiences in the revolution were a combination of brave heroism and disappointment. By acting as fighters, women revolutionaries assumed that they would share in decision-making, planning, and other important tasks during the war. They also expected to be given the same treatment as male veterans after the war. ${ }^{33}$ In the years following independence, there was a national myth of women's militarization evoked in films like The Battle of Algiers that unrealistically portrayed women and men as equals in the war. In reality, no woman was ever in a leadership position in the FLN. ${ }^{34}$ In 1974, Algeria's Ministry for Veteran's Affairs estimated that about 11,000 women fought in the war (making up about 3\% of all participants), although this is now thought to be a serious underestimation. The majority of positions women held during the war were still bound to the same societal gender norms, particularly for women living in rural areas who unofficially fought for the FLN. Women who performed the same jobs as men were called "helpers" or "nurturers." ${ }^{35}$ They were often confined to tasks that would not

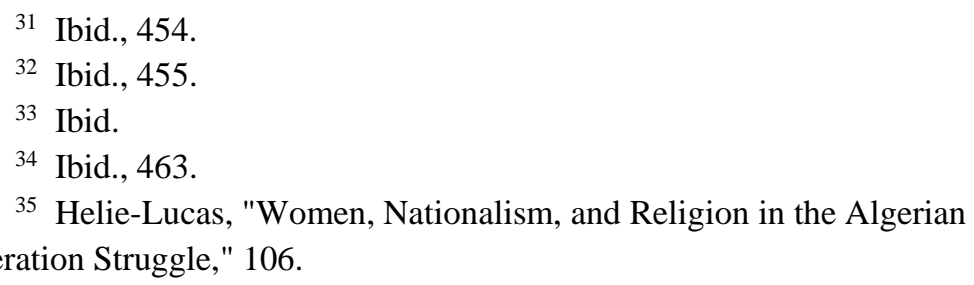


"disturb the social order in the future"36: they hid food, acted as guides, collected medicine and ammunition, nursed soldiers, did cooking and washing, and performed secretarial work. Since most fighting occurred in rural areas, these women (mostly poor, illiterate, un-educated peasants) would help hide soldiers, carry messages, and observe the movements of the French army. Despite their contributions, very few rural women were praised for their actions or registered as veterans to receive benefits after the war had ended. ${ }^{37}$

The situation was hardly better for female fighters in urban areas. Although most of the attention on Algerian women during the war focuses on the most visible urban fighters, they were the minority: only a small percentage of women carried out terrorist attacks or were armed fighters. ${ }^{38}$ Despite this disparity, the French military and police did not spare women revolutionaries: about 2,200 women were arrested and tortured during the war. ${ }^{39}$ Many women were also subjected to rape: since virginity is highly regarded in Algeria culture as a facet of their Islamic religion, rape was a "particularly potent method of torture and abuse for women suspected of being nationalists." 40 Female fighters were also frequently discriminated against within the independence movement because of their gender. Fears and suspicions about women's "sexual vulnerability” influenced their treatment by other members. ${ }^{41}$ Although the FLN used European-looking women as spies to gain information from French

36 Ibid., 107.

37 Meredith Turshen, "Algerian Women in the Liberation Struggle and the Civil War: From Active Participants to Passive Victims?," Social Research 69, no. 3 (2002): 890.

38 Helie-Lucas, "Women, Nationalism, and Religion in the Algerian Liberation Struggle,"106.

39 Turshen, "Algerian Women in the Liberation Struggle and the Civil War: From Active Participants to Passive Victims?," 891.

40 Vince, "Transgressing Boundaries,” 459.

41 Joseph and Slyomovics, Women and Power in the Middle East, 28. 
soldiers by gaining their trust and starting relationships, they also worried that their female spies would be vulnerable to seduction by French men. Women were seen as potentially dangerous weapons whose sexuality was a weakness. ${ }^{42}$

Despite these difficult conditions, the majority of female fighters remained dedicated to the revolutionary cause. Most of the women who joined the FLN were young and in their early twenties. ${ }^{43}$ Although they did expect a certain level of equality once the war was over, feminism was not necessarily a major guiding ideology for many female recruits. For them, women's liberation was essentially on hold until national liberation had been achieved. Algerian author and activist Marie-Aimée Helie-Lucas, who experienced the war, wrote that many Algerian women did not question the priority of liberating the country over gender equality, since they believed "independence would surely end discrimination." ${ }^{44}$ She describes widespread "brainwashing" and "blind obedience" that kept women from questioning their second-class status. ${ }^{45}$ Women remained silent in the name of national solidarity for fear of being seen as betraying the revolution. ${ }^{46}$ If they spoke out against the FLN, they feared the French would use their dissent to "undermine socialist ideas of justice and equality." ${ }^{47}$

On the other side of the conflict, there were a small number of Algerian women who resisted the FLN, choosing to instead side with the French colonists. In the 1950s, a small group of mostly upper class, French-educated Algerian women (called "évoluées" or evolved women) began to speak out against the resistance movement. The

42 Vince, “Transgressing Boundaries,” 456.

43 Ibid., 459.

${ }^{44}$ Helie-Lucas, "Women, Nationalism, and Religion in the Algerian Liberation Struggle,” 107.

45 Ibid.

${ }^{46}$ Ibid.

47 Ibid., 111. 
évoluées were exactly the kind of women the French government and supporters of l'Algérie française hoped to advertise in France as benefiting from their reforms, exemplifying the need to "save" even more Algerian women from the FLN. ${ }^{48}$ Some women, like Algerian author Djamila Debeche, advocated for Western-style feminism and embraced the French reforms. She believed traditions like veiling were "antithetical to modernization" and emphasized the importance of integration of French and Algerian cultures. ${ }^{49}$ She was called an anti-nationalist, because her writing implied that male oppression was worse than the "biculturalism born of colonial oppression." 50

She was also criticized by nationalists for representing only a small minority of privileged, wealthy women, accentuating the socioeconomic, as well as political, conflicts latent in the revolution. ${ }^{51}$ Of the handful of prominent Algerian feminist voices during this time, few had an audience that reached beyond the urban upper classes. Feminism in Algeria was seen as a Western construct created by colonialism, incompatible with the nationalist ideology of the FLN. However, while the évoluées supported the French cause and were praised for it, they were still excluded from the same status or treatment as women in metropolitan France. ${ }^{52}$

After independence was declared on July $5^{\text {th }}$, 1962 , it was unclear how, or if, the new government would embrace women's rights. Women believed that because they had sacrificed and fought alongside men they had earned the right to be recognized as equals in the new independent state they had fought for. ${ }^{53}$ Although the situation at first looked positive, with the adoption of education reforms targeting women, internal political divisions within the

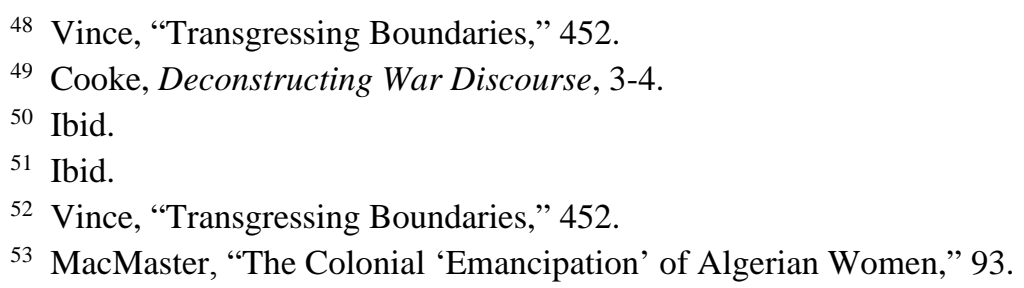


government spoiled any chance at achieving gender equality. HelieLucas writes: "Socialism, nationalism, and religion became tools for the elaboration of an anti-women state policy." 54 After independence, the ruling FLN party became especially conservative and restrictive towards women's rights, partly as a reaction to the French colonists' efforts at modernization and secularism. ${ }^{55}$ This refusal to acknowledge or accept any ideology related to the West was typical of many postcolonial governments throughout the Middle East. ${ }^{56}$

Perhaps blinded by his support of Algerian liberation, Frantz Fanon wrote during the war that "women's status had been changed as a result of their participation; they were now equals." ${ }^{57}$ The postrevolution reality could not have been more different. Attitudes towards women's rights in Algerian society continued to evolve in the form of strict marriage and divorce laws, increased rates of domestic violence, lack of women's education, forced veiling, banning of birth control, unemployment, harassment, and seclusion. ${ }^{58}$ Despite their brave actions and sacrifices during the revolution, women's contribution to the liberation struggle was largely seen as symbolic at best. During the war, women's willingness and enthusiasm for the liberation cause was exploited just as much as the assumption that their loyalty could be acquired by the promise of marriage reform. The appropriation of women's identity for ideological purposes by both Algerian and French forces profoundly influenced how their image and story was portrayed to the world, effectively preventing women's voices from becoming part of an authentic discourse on the war after independence.

54 Helie-Lucas, "Women, Nationalism, and Religion in the Algerian Liberation Struggle,” 104.

55 Keddie, Women in the Middle East, 143.

56 Ibid., 218.

57 Vince, “Transgressing Boundaries,” 446.

58 Helie-Lucas, "Women, Nationalism, and Religion in the Algerian Liberation Struggle,” 110. 
Anthós, Vol. V, Issue 1

\section{Bibliography}

Ahmed, Leila. Women and Gender in Islam: Historical Roots of a Modern Debate. New Haven, CT: Yale University Press, 1993.

Amrane-Minne, Daniele Djamila, and Farida Abu-Haidar. "Women and Politics in Algeria from the War of Independence to Our Day." Research in African Literatures 30, no. 3 (1999): 62-77.

The Battle of Algiers. Dir. Gillo Pontecorvo. 1966. DVD.

Cooke, Miriam. Deconstructing War Discourse: Women's Participation in the Algerian Revolution. East Lansing: Michigan State University, 1989.

Helie-Lucas, Marie-Aimee. "Women, Nationalism, and Religion in the Algerian Liberation Struggle." In Opening the Gates: An Anthology of Arab Feminist Writing, edited by Margot Badran and Miriam Cooke. 2nd ed. Bloomington: Indiana University Press, 2004.

Joseph, Suad, and Susan Slyomovics, eds. Women and Power in the Middle East. Philadelphia: University of Pennsylvania Press, 2000.

Keddie, Nikki R. Women in the Middle East: Past and Present. Princeton, New Jersey: Princeton University Press, 2006.

MacMaster, Neil. "The Colonial "Emancipation” of Algerian Women: the Marriage Law of 1959 and the Failure of Legislation on Women's Rights in the PostIndependence Era." Vienna Journal of African Studies 12 (2007): 91-116.

Turshen, Meredith. "Algerian Women in the Liberation Struggle and the Civil War: From Active Participants to Passive Victims?" Social Research 69, no. 3 (2002): 889-911.

Vince, Natalya. "Transgressing Boundaries: Gender, Race, Religion, and "Françaises Musulmanes” during the Algerian War of Independence." French Historical Studies 33, no. 3 (2010): 445-474. 